\title{
32. RADIOMETRIC AGES OF BASEMENT LAVAS RECOVERED AT LOEN, WODEJEBATO, MIT, AND TAKUYO-DAISAN GUYOTS, NORTHWESTERN PACIFIC OCEAN ${ }^{1}$
}

\author{
Malcolm S. Pringle ${ }^{2}$ and Robert A. Duncan ${ }^{3}$
}

\begin{abstract}
The best estimate for the age of the oldest volcanism recovered from the summits of Loen, Wodejebato, MIT, and TakuyoDaisan guyots, northwestern Pacific Ocean, is 113, 83, 123, and $118 \mathrm{Ma}$, respectively. All of these sites originated in the central and western regions of the South Pacific Isotopic and Thermal Anomaly (SOPITA). The 113-Ma age for Loen Guyot is significantly different from the 76-Ma age of volcanism under the carbonate platform of its neighbor, the living Anewetak Atoll, and suggests that drowned guyot/living atoll seamount pairs may have no genetically significant relationship other than geographic proximity. Although all of the basalts recovered from the top of Wodejebato Guyot were erupted during polarity Chron 33R (ca. 79-85 Ma), both the occurrence of reworked Cenomanian calcareous nannofossils in one of the summit cores and the existence of a thick Cenomanian volcaniclastic sequence, including 94-Ma basaltic clasts, in the archipelagic apron indicate that there must have been a Cenomanian or older edifice beneath the drilled summit volcanics. AT MIT Guyot, two late-stage periods of volcanism can be recognized: late Aptian (ca. $115 \mathrm{Ma}$ ) phreatomagmatic eruptions through the existing volcanic and carbonate platform, and 120-Ma hawaiites seen both as exotic clasts in the 115-Ma tuffs and as lava flows at the top of the basement sequence. Also, the $122.9 \pm 0.9 \mathrm{Ma}$ age of two lavas in the basement lava sequence date the upper boundary of the reversed polarity Chron M1R, providing an important calibration point for the Cretaceous Geological Reversal Time Scale. The 118-Ma age of volcanism a Takuyo-Daisan Guyot is best constrained by the age of dredge basalts from its flanks and those of its neighbor to the southwest, Takuyo-Daini Seamount, but agrees well with the oldest sediments recovered at Hole 879A.
\end{abstract}

\section{INTRODUCTION}

Geochronological control through the radiometric dating of seamount basalts provides constraints central to almost all of the scientific objectives of the Guyots and Atolls Drilling Program, Ocean Drilling Program (ODP) Legs 143 and 144: age of principal edifice formation, maximum age of initial reef formation, timing of platform drowning, timing of relative changes in sea level and/or vertical tectonics, timing of seamount paleolatitude changes, and the longevity of the mantle source of SOPITA/Dupal lavas.

Leg 144 reached volcanic basement at the nine sites on the summits of five guyots in the northwestern Pacific Ocean (Fig. 1). Six of these sites had material suitable for ${ }^{40} \mathrm{Ar} /{ }^{39} \mathrm{Ar}$ dating: Site 872 on Loen Guyot and Sites 873,874 , and 876 on Wodejebato Guyot in the Marshall Islands; Site 878 on MIT Guyot north of the Marcus-Wake Seamount Group; and Site 879 on Takuyo-Daisan Guyot in the Seiko cluster of the Japanese Seamounts. In addition, Leg 143 recovered volcanic material suitable for ${ }^{40} \mathrm{Ar} /{ }^{39} \mathrm{Ar}$ dating at Site 869 on the archipelagic apron of Wodejebato Guyot and its sister seamount, Pikini Atoll (Pringle and Duncan, 1995). Finally, two dredges recovered during the Aries V expedition of the Scripps Institute of Oceanography from seamounts in the Seiko cluster of the Japanese Seamounts, including Takuyo-Daisan, recovered material with important implications for the timing of volcanism in that seamount group. The purpose of this study is to provide reliable age estimates for each of these sites of volcanism.

\footnotetext{
'Haggerty J.A., Premoli Silva, I., Rack, F., and McNutt, M.K., (Eds.), 1995, Proc. ODP, Sci. Results, 144: College Station, TX (Ocean Drilling Program).

${ }^{2}$ Center for Isotope Geology, Faculty of Earth Sciences, Free University, De Boelelaan 1085, 1081 HV Amsterdam. The Netherlands. (Present address: Scottish Research and Reactor Centre, East Kilbride, Glasgow G75 0QU, Scotland.)

${ }^{3}$ College of Oceanic and Atmospheric Sciences, Oregon State University, Corvallis, OR 97331 , U.S.A.
}

\section{SITE SUMMARIES AND SAMPLES STUDIED Loen Guyot (Site 872)}

Three holes were drilled at Site 872 near the center of Loen Guyot. Hole $872 \mathrm{~B}$ penetrated about $57 \mathrm{~m}$ into basement; Sample 144-872B$9 \mathrm{R}-2,115-120 \mathrm{~cm}$, is an aphyric hawaiite from one of the lowermost units. We crushed and leached this sample to dissolve a significant amount of the $10 \%-15 \%$ of green-brown clay in an otherwise fresh, holocrystalline but very fine-grained, trachytic groundmass. Holc $872 \mathrm{C}$ recovered about $2 \mathrm{~m}$ of titanaugite- and olivine-microphyric differentiated alkalic basalt. Sample $144-872 \mathrm{C}-18 \mathrm{X}-1,88-93 \mathrm{~cm}$, is from one of the freshest pieces, with $10 \%-15 \%$ clay in a nearly holocrystalline, relatively coarse-grained, intergranular groundmass.

The oldest sediments found at Site 872 were Coniacian to early Santonian pelagic limestones filling fractures in the uppermost basalts (Fig. 2; Erba et al., this volume). The normal polarity of the basalts supports a mid Cretaceous eruption age of the volcanic basement, during the long Cretaceous Normal Polarity Superchron (Premoli Silva, Haggerty, Rack, et al., 1993). No evidence for a shallow-water limestone platform at Loen Guyot was recovered at Site 872. However, Lincoln et al. (1993) describe material dredged from the southern slopes of Loen Guyot that suggest that a shallow platform capped the guyot in the early or middle Albian, but that the guyot was already into the pelagic environment by the latest Albian.

\section{Wodejebato Guyot Summit (Sites 873 through 877)}

Five sites were drilled on the summit of Wodejebato Guyot: Site 873 near the center of the guyot, Sites 874 and 877 on the inner perimeter ridge, and Sites 875 and 876 on the outer perimeter ridge (Premoli Silva, Haggerty, Rack, et al., 1993). Hole 873A was the only site with significant basement penetration, drilling through a $19-\mathrm{m}-$ thick claystone developed through extensive weathering of the underlying basalts, $29 \mathrm{~m}$ of lava flows, and bottoming in $28 \mathrm{~m}$ of debrisflow breccias. Samples 144-873A-17R-1, 23-27 cm, and -18R-1, 


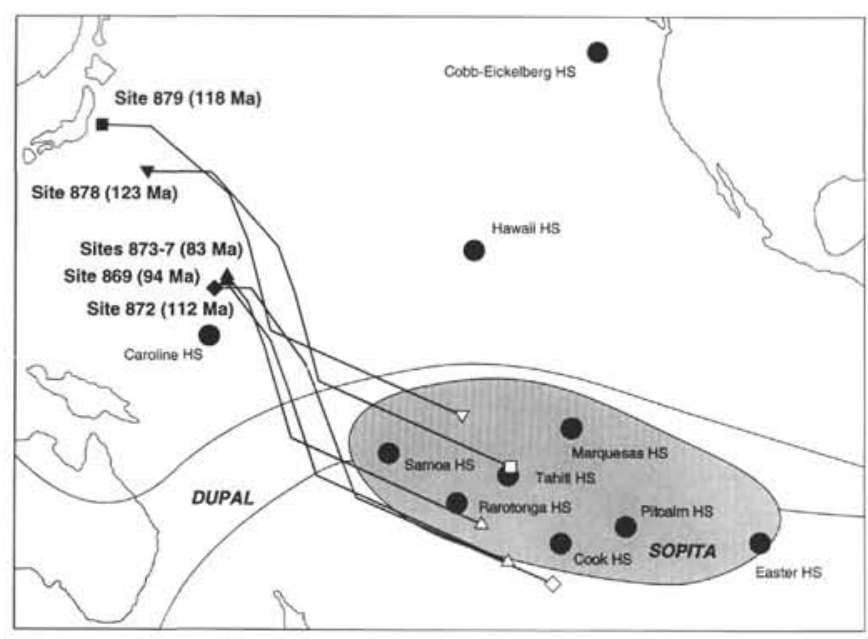

Figure 1. Present-day (solid squares and triangles) and original (open squares and triangles) locations of the volcanism sampled at Sites 869, 872, 873-877. 878 , and 879 , Legs 143 and 144 . Original locations calculated by backtracking the present-day locations using the weighted ages given in Table 1 and the rotation poles of Duncan and Clague (1985). Note that the volcanic source of the $869 \mathrm{~B}$ apron site was probably about $45 \mathrm{nmi}$ to the northeast, near the summit of Wodejebato Guyot, represented by Sites 873-877. Also shown are locations of the modern SOPITA of Staudigel et al. (1991), the DUPAL anomaly of Hart (1984), and the modern active Pacific hotspots.

14-18 cm, are aphyric, microcrystalline differentiated alkalic basalt or hawaiite flows. Hole $874 \mathrm{~B}$ penetrated $15 \mathrm{~m}$ of claystone before bottoming in $16 \mathrm{~m}$ of a single ankaramite flow, Sample 144-874B$24 \mathrm{R}-4,106-111 \mathrm{~cm}$, is among the freshest pieces, with $5 \%-10 \%$ green clay and brown glass in an otherwise holocrystalline groundmass (and with relatively fresh olivine phenocrysts). Holes $875 \mathrm{C}$ and $876 \mathrm{~A}$ passed directly from shallow-water limestones into basaltic basement, with little or no indication of an intervening weathering horizon. Hole $875 \mathrm{C}$ bottomed in $9 \mathrm{~m}$ of altered basalts, whereas Hole $876 \mathrm{~A}$ bottomed in $14.5 \mathrm{~m}$ of at least three distinct basalt flows. Sample 144-876A-17R-1, 91-98 cm, is a sparsely olivine- and clinopyroxene-phyric, fine-grained alkalic basalt, whereas Sample 144$876 \mathrm{~A}-17 \mathrm{R}-1,98-104 \mathrm{~cm}$, is a plagioclase-microphyric, mediumgrained alkalic basalt; both have $10 \%-20 \%$ green-brown clay in an otherwise holocrystalline groundmass.

All of the sites drilled on the summit of Wodejebato Guyot recovered evidence of a Late Cretaceous shallow-water limestone platform (Premoli Silva, Haggerty, Rack, et al., 1993; Erba, this volume, Premoli Silva et al., this volume). The most age-diagnostic fossil assemblage, nannofossil Zone CC22 of middle Campanian age, was found in a series of carbonaceous clay and argilleous limestone underlying the platform carbonate sequence at Site 877; similar assemblages were found at Holes 873A and 874B (Fig. 2; Erba et al., this volume). The youngest assemblages at Sites 873,874 , and 877 are similar in age to the oldest assemblages found at Sites 875 and 876 , from the late Campanian to early Maastrichtian $G$. gansseri planktonic foraminifer zone. All of the basement lavas recovered at Wodejebato Guyot are reversely magnetized and have been attributed to Chron 33R of early Campanian age (Nakanishi and Gee, this volume; Premoli Silva, Haggerty, Rack, et al., 1993). However, the argilleous limestone layers at Site 877 also contain reworked Cenomanian calcareous nannofossils, indicating that only the most recent part of the basement edifice of Wodejebato Guyot has been recovered at Sites 873 through 877.

\section{Wodejebato/Pikini Apron (Site 869, Leg 143)}

Site 869 was chosen as an archipelagic apron site, $75 \mathrm{~km}$ to the southeast of the Wodejebato/Pikini Guyot/Atoll pair in the northern
Marshall Islands. The upper part of Hole 869B penetrated $208 \mathrm{~m}$ of an upper Miocene to upper Maastrichtian-lower Campanian pelagic ooze, porcellanite, and chert (Sager, Winterer, Firth, et al., 1993). The lower part of Hole $869 \mathrm{~B}$ penetrated nearly $600 \mathrm{~m}$ of repeated sequences of Late Cretaceous volcaniclastic sandstones and breccias deposited against a background of pelagic nannofossil and radiolarian claystone. The episodic nature of the supply of the volcaniclastic sediments resulted in a distinctly nonuniform rate of deposition (Sager, Winterer, Firth, et al., 1993):

\begin{tabular}{lr}
\hline \multicolumn{1}{c}{ Age } & $\begin{array}{c}\text { Thickness } \\
(\mathbf{m})\end{array}$ \\
\hline late Maastrichtian/early Campanian & 29 \\
Campanian & 174 \\
late Santonian & 19 \\
Turonian-Coniacian & 48 \\
late to middle/late Cenomanian & 328 \\
\hline
\end{tabular}

In particular, a nearly 50 -m-thick subunit of volcaniclastic debris and grain flows in the center of the late Cenomanian section contained angular to subrounded basaltic clasts as much as $8 \mathrm{~cm}$ in diameter. We chose three clasts from this subunit for dating: hawaiite (Sample 143-869B-41R-5, 82-85 cm) for whole-rock analysis (fine-grained yet holocrystalline trachytic groundmass), and plagioclase-pyroxeneolivine phyric (Samples 1-869B-41R-2, 84-86 cm, and -41R-4, 70$73 \mathrm{~cm}$ ) for analysis of plagioclase separates. We have not yet tried to date any volcanic material from the Campanian section, but a dateable sample would probably have to be a bulk plagioclase separate from the volcaniclastic sandstone matrix unless individual crystals of biotite or hornblende could be found.

\section{MIT Guyot (Site 878)}

The lowermost sections recovered at Site 878, located just inside the southern perimeter ridge of MIT Guyot, consist of a 187-m-thick basement section of subaerial alkalic lavas flows, overlain by $100 \mathrm{~m}$ of platform carbonates and more than $200 \mathrm{~m}$ of volcanogenic polymict breccia (Fig. 3; Premoli Silva, Haggerty, Rack, et al., 1993). The basement section itself can be divided into three main compositional groups separated by significant weathering horizons: an upper 10-m-thick sequence of hawaiites, a middle 46-m-thick sequence of titanaugite-rich basanitoids, and a lower 110-m-thick sequence of plagioclase-rich basanitioids and alkalic basalts. An especially welldeveloped tropical weathering profile, preserved as an 8-m-thick claystone, is present between the middle basanitoids and lower basalts. The polymict breccia is interpreted as the product of a series of phreatomagmatic eruptions through the underlying basalt and platform carbonate succession. We chose five whole-rock samples from the basement section: three of the lower alkali olivine basalts (from Sections 144-878A-98R-3, -91R-3, and -89R-4), a basanite from the middle lavas (Section 144-878A-80R-6), and a plagioclase-phyric hawaiite from the upper lavas (Section 144-878A-79R-3). In addition, we chose two clasts from the polymict breccia: an (originally) olivine-phyric alkalic differentiate or hawaiite from Section 144$878 \mathrm{~A}-46 \mathrm{M}-1$, and a plagioclase-phyric hawaiite from Section 144$878 \mathrm{~A}-46 \mathrm{M}-2$. Both of these clasts appear to be exotic fragments similar to the upper hawaiite flows in the basement section. None of the juvenile material in the polymict breccia was found to be fresh enough for ${ }^{40} \mathrm{Ar} /{ }^{39} \mathrm{Ar}$ geochronology.

The biostratigraphic constraints on the age of the sediments at Site 878 are summarized in Figure 3. Platform carbonates from Core 144-878 A-41M, just above the top of the polymict breccia, are attributable to the late Aptian N. truittii Acme of Mutterlose (1991) and the G. algerianus $-H$. trocoidea planktonic foraminifer Zones (Premoli Silva, Haggerty, Rack, et al., 1993; Erba et al., this volume). Platform carbonates from Core 144-878A-75R, $25 \mathrm{~m}$ above volcanic basement, are earliest Aptian in age (i.e., above the first occurrence of $R$. irregularis), which defines the base of the $C$. litterarius nannofossil 


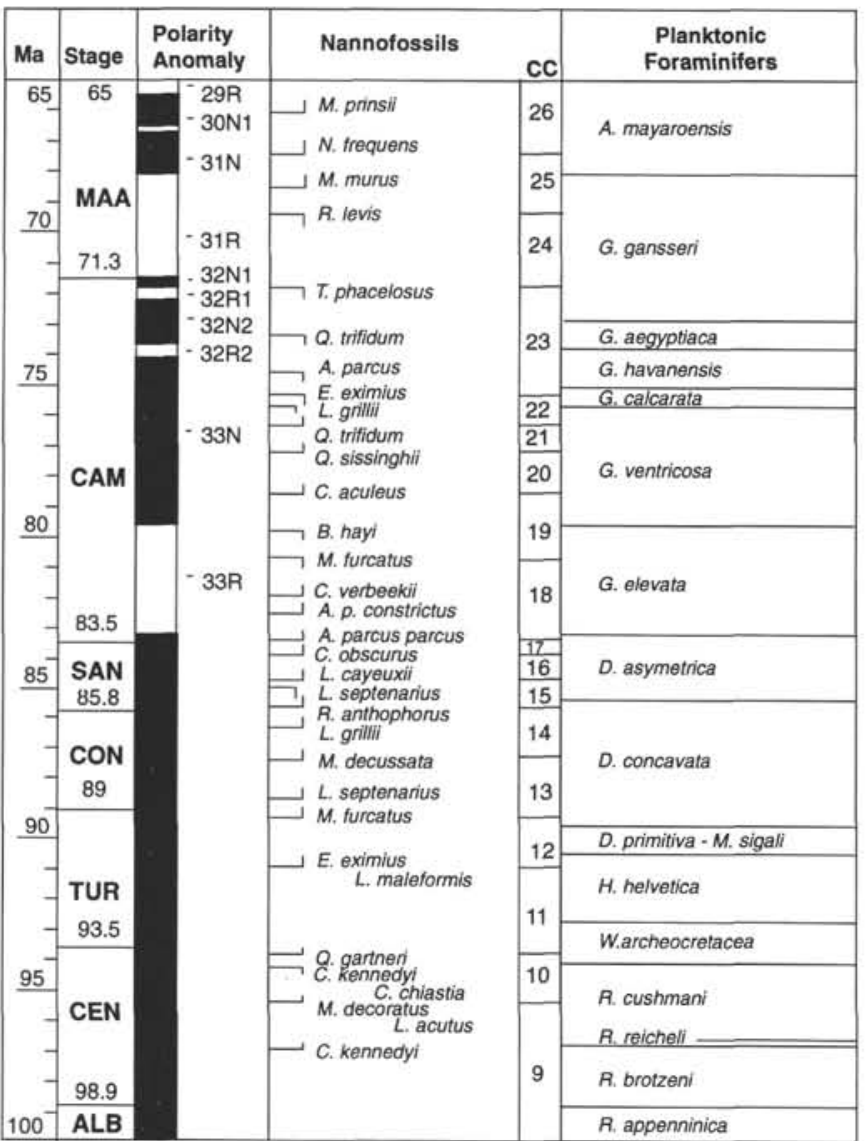

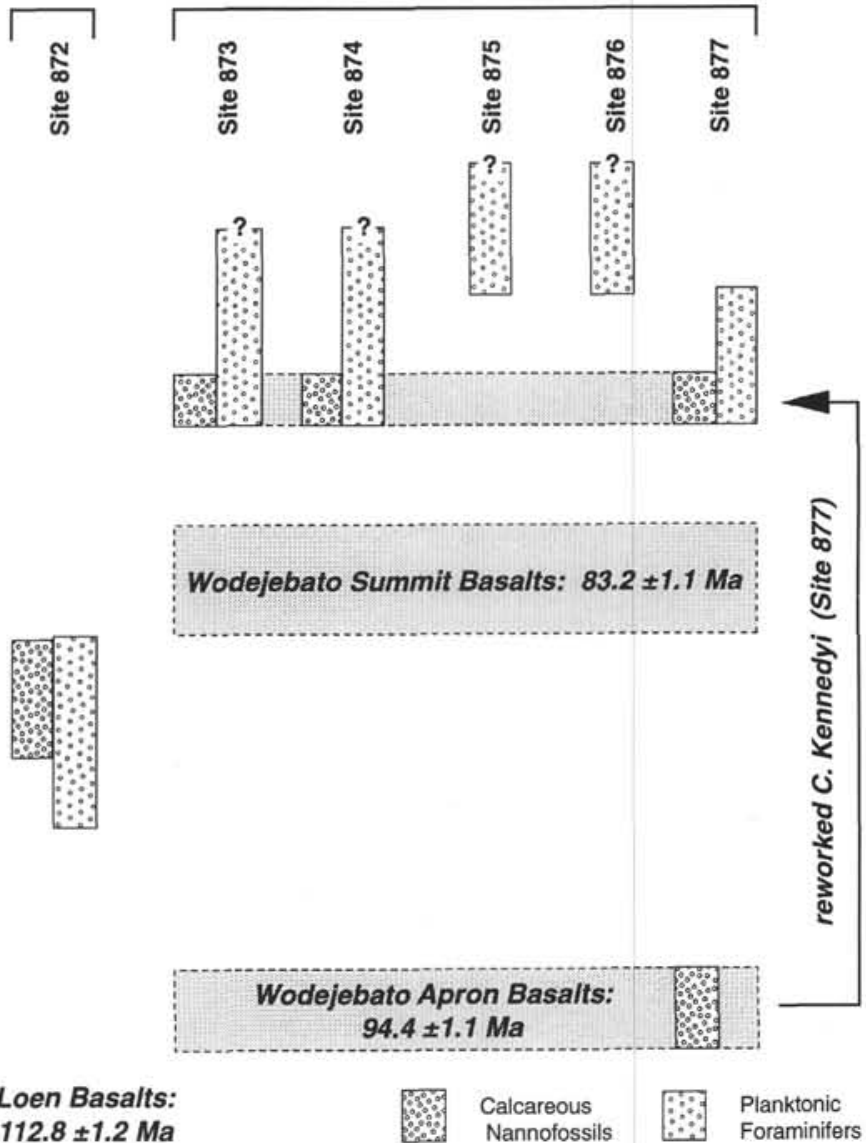

Figure 2. Age of the volcanic basement at the summit of the Wodejebato Guyot ( $83.2 \mathrm{Ma})$ and volcanic clasts found in the archipelagic apron $45 \mathrm{nmi}$ to the southwest ( $94.4 \mathrm{Ma}$ ), compared with the oldest sedimentary rocks found at the summit. Note that all of the volcanic basement drilled at Wodejebato, including the undated breccias such as those at the base of Hole 873A, is reversely magnetized and must have been erupted during magnetic Chron 33R. Biostratigraphy from Erba et al. (this volume) and Premoli Silva et al. (this volume); time scale from Gradstein et al. (in press).

zone but below the "nannoconid crisis" (Premoli Silva, Haggerty, Rack, et al., 1993; Erba, 1994; Erba et al., this volume).

The magnetostratigraphy of the sedimentary and volcanic sequences, also shown in Figure 3, has important implications for the age of the basement at MIT Guyot. All of the samples examined from the sedimentary platform sequence, including the polymict breccia, were normally magnetized (Premoli Silva, Haggerty, Rack, et al., 1993). Their biostratigraphic age (see Fig. 3) indicates that all of the sedimentary platform sequence was deposited during the long Cretaceous Normal Polarity Superchron (K-N). Of course, drilling recovery is poor in such sequences, especially in recovering pieces large enough to determine the original orientation of the sample. Thus, it is possible that a reversal has been missed. In fact, although no samples were actually reversed, one sample from the lower limestone section (Premoli Silva, Haggerty, Rack, et al., 1993; Nakanishi and Gee, this volume) did have an anomalously shallow inclination, perhaps suggestive of a reversal just above or below.

A magnetic reversal does, however, occur in the basalt sequence (Premoli Silva, Haggerty, Rack, et al., 1993). According to shorebased measurements on discrete samples (Nakanishi and Gee, this volume), all of the flows from the upper hawaiite and middle basanitoid sequences are normally magnetized, the uppermost lower alkalic basalts (Sections 144-878A-86R-2 to-90R-2) have transitional polarity directions, and all of the flows below Section 144-878A-90R-3 are reversely magnetized. According to the downhole magnetometer logs (Ito and Nogi, this volume), the reversal occurs somewhere between
Sections 144-878A-90R-4 and -92R-2. Using the biostratigraphy discussed above and the time scales of Harland et al. (1990) and Gradstein et al. (in press), the reversal seen in the basalts is most likely either M0 or M1 (shown as M1 in Fig. 3; see discussion below).

\section{Takuyo-Daisan Guyot (Site 879 and Dredge Samples)}

Hole $879 \mathrm{~A}$ is located on the perimeter ridge of Takuyo-Daisan Guyot in the Seiko cluster of the Japanese Seamounts (Fig. 1). Drilling bottomed in about $20 \mathrm{~m}$ of an intercalated mixture of plagioclasephyric basalt and volcanic breccia or peperite (i.e., formed by the intrusion of the basaltic lava into a soft, wet sediment). Both the basalt and the volcanic breccia are pervasively altered and variably discolored to various shades of reds and greens (Premoli Silva, Haggerty, Rack, et al., 1993). Apparently fresh plagioclase from two of the fresher pieces of basalt was separated for ${ }^{40} \mathrm{Ar} /{ }^{39} \mathrm{Ar}$ dating. Also, two samples dredged from Takuyo-Daisan and its southwestern neighbor, Takuyo-Daini, during the Aries V expedition of the Scripps Institute of Oceanography (Heezen et al., 1973; Winterer et al., 1993) were chosen for ${ }^{40} \mathrm{Ar} /{ }^{39} \mathrm{Ar}$ dating to help elucidate the age of basement volcanism in the Seiko Cluster of the Japanese Seamounts.

The age of the oldest sedimentary rocks above the peperite at Site 879 is similar in to those just above the polymict breccia at MIT Guyot (Fig. 3), with assemblages diagnostic of the $N$. truittii Acme and $G$. algerianus $-H$. trocoidea Zones, or the late Aptian. 


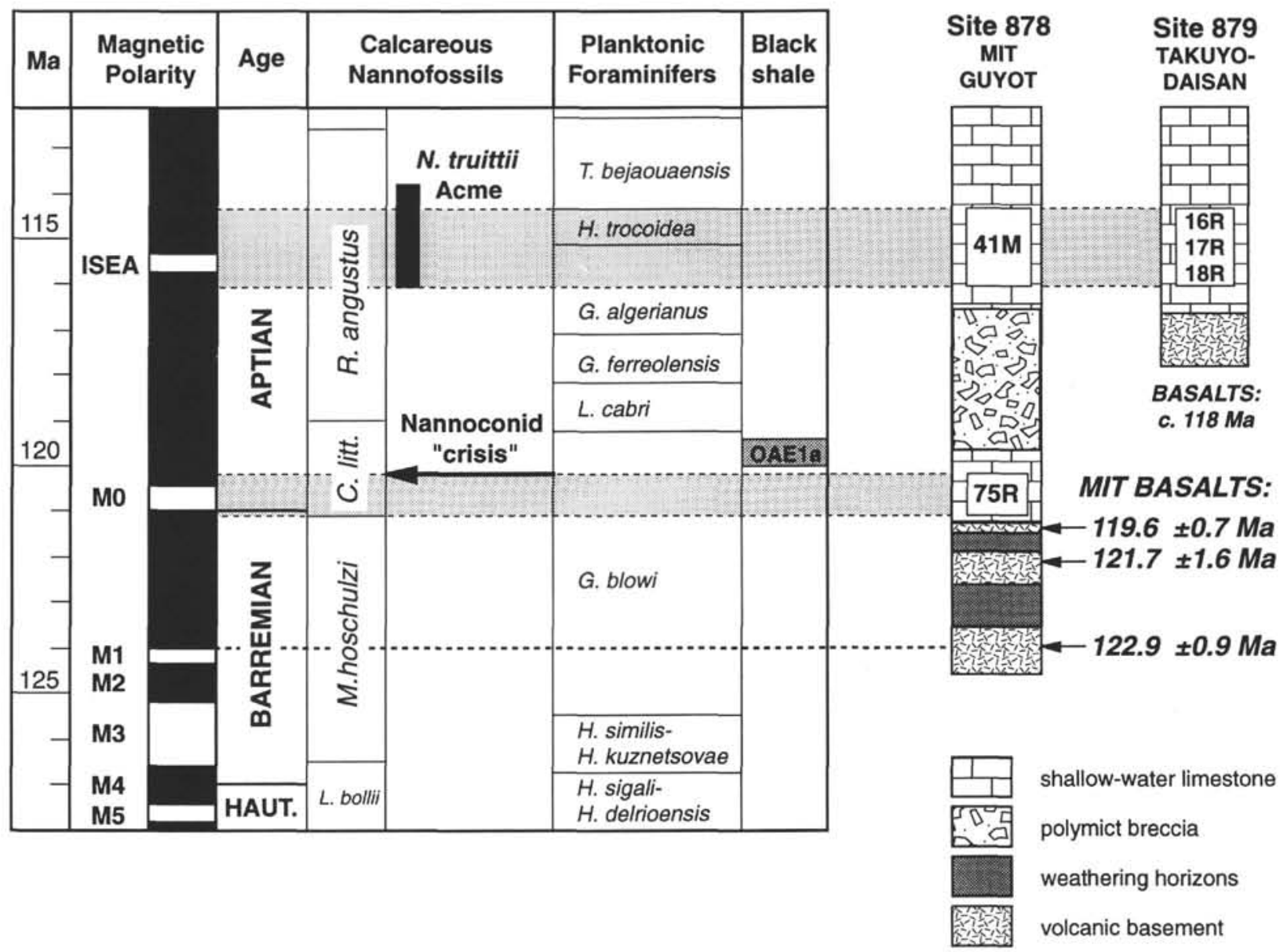

Figure 3. Age of the volcanic basement MIT Guyot and Takuyo-Daisan Guyot, Sites 878 and 879, respectively, compared with the oldest sedimentary rocks found at those sites. Biostratigraphy from Erba et al. (this volume) and Premoli Silva et al. (this volume); time scale from Gradstein et al. (in press).

\section{K-Ar GEOCHRONOLOGY}

The $\mathrm{K}-\mathrm{Ar}$ clock, and especially the ${ }^{40} \mathrm{Ar} /{ }^{39} \mathrm{Ar}$ technique, has been widely used to date oceanic lavas. However, care must be used in the interpretation of such data because several fundamental assumptions of the technique are almost certainly violated by samples that have been altered in the submarine environment. The advantage of using the ${ }^{40} \mathrm{Ar} /{ }^{39} \mathrm{Ar}$ method for deciphering the crystallization age of altered rocks is that accurate ages can be differentiated from unreliable dates using a series of internal tests for a set of apparent ages from any given sample. It may not be possible to differentiate why a particular age from a sample is unreliable, although alteration processes are clearly a contributing factor (see Pringle, 1993, for a more complete discussion). However, one can test whether the K-Ar clock of a particular sample is too disturbed to reveal a meaningful age.

\section{Criteria for Interpreting ${ }^{40} \mathrm{Ar} /{ }^{39} \mathrm{Ar}$ Apparent Ages}

To test whether a sample can reveal a reliable ${ }^{40} \mathrm{Ar} /{ }^{39} \mathrm{Ar}$ age, one must first generate a set of ages upon which to apply the criteria presented below. For relatively low-potassium, moderately to highly altered samples, we have found that step-heating experiments provide the most useful sets of apparent ages. This is principally because low-temperature alteration phases tend to release their gas at lower temperatures, allowing us to examine the higher temperature gas release, presumably from higher temperature igneous phases, for a pattern representative of a concordant crystallization age.

Following Pringle (1993), we modify the conservative criteria of Lanphere and Dalrymple (1978) and Dalrymple et al. (1980) so that each criterion involves the use of a rigorous statistical test. We apply these criteria to a set of apparent ages for a given sample. We accept that this set of apparent ages represents an accurate estimate of the crystallization age of the sample only if:

1. No age difference can be detected between any of the individual ages at the $95 \%$ confidence level. For an incremental heating experiment, these ages should represent a well-defined, hightemperature age plateau representing three or more contiguous steps that contain at least $50 \%$ of the ${ }^{39} \mathrm{Ar}$ released.

2. A well-defined isochron exists for the set (i.e., the $\mathrm{F}$ ratio statistic for the regression is sufficiently small at the $95 \%$ confidence level). If this ratio is exceeded, then there is more scatter about the isochron than can be explained by analytical error alone, and some additional geologic or experimental disturbance is significant.

3. The weighted mean plateau age from criterion 1 and the isochron age from criterion 2 are not significantly different at the $95 \%$ confidence level.

4. The ${ }^{40} \mathrm{Ar} /{ }^{66} \mathrm{Ar}$ intercept from the isochron analysis in criterion 2 is not significantly different from the atmospheric value of 295.5 at the $95 \%$ confidence level.

\section{Techniques}

Samples for whole-rock incremental heating experiments were slabbed and trimmed to obtain the freshest and most holocrystalline material. The Aries V samples were crushed to about $0.5-1 \mathrm{~mm}$ in size, hand-picked to remove vesicle and vein alteration, and cleaned in an ultrasonic bath with deionized water; the ODP drill-core sam- 

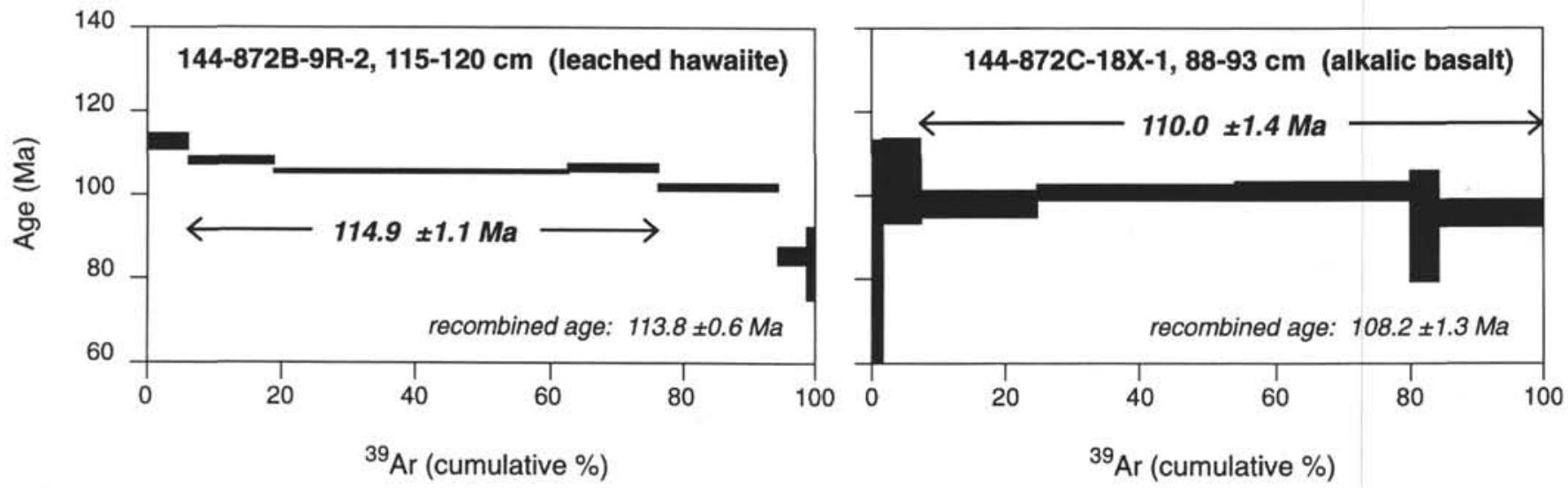

Figure 4. Age spectra of incremental heating experiments on whole-rock samples from Loen Guyot, Site 872 . Individual step ages are drawn \pm 1 standard deviation of the apparent age.

ples were prepared as 6-mm cores drilled from the freshest sections of the 1-cm-thick slabs. Plagioclase mineral separates were prepared using conventional heavy liquid and magnetic techniques, and further cleaned with cold 5\%-10\% $\mathrm{HF}$, warm $3 \mathrm{~N} \mathrm{HCl}$, and, finally, distilled water in an ultrasonic bath. One sample was prepared as a groundmass separate by crushing to 125 to $250 \mu \mathrm{m}$, cleaning with warm $3 \mathrm{~N}$ $\mathrm{HCl}$, and rinsing with distilled water in an ultrasonic bath.

The whole-rock samples, about $0.5 \mathrm{~g}$ each, and the plagioclase and leached groundmass separates, about $15 \mathrm{mg}$ each encapsulated in $\mathrm{Cu}$ foil packets, were sealed in fused-silica vials and irradiated for $6-12 \mathrm{hr}$ in the core of the Oregon State University TRIGA reactor. The efficiency of the conversion of ${ }^{39} \mathrm{~K}$ to ${ }^{39} \mathrm{Ar}$ was monitored with $27.92 \mathrm{Ma}$ 85G003 TCR sanidine except for the two Aries V dredge samples, for which 27.7 Ma FCT-3 biotite was used. Corrections for interfering Kand Ca-derived Ar isotopes are those from Dalrymple et al. (1981). ${ }^{40} \mathrm{~K}$ decay constants used were $\lambda \mathrm{E}=0.581 \cdot 10^{-10}$ and $\lambda \mathrm{B}=4.962 \cdot 10^{-10}$.

Argon extractions for the whole-rock samples were performed in a conventional high-vacuum glass extraction line using radiofrequency induction heating. The cleanup system consisted of a series of two titanium furnaces held at about $800^{\circ} \mathrm{C}$ to getter the reactive gases, and subsequently cooled to get hydrogen. Heating steps, each 20 min long, used fixed power levels on the RF generator, determined from previous experience to divide the Ar release into five to seven roughly equal proportions, and ranged from about $600^{\circ}$ to $1300^{\circ} \mathrm{C}$ in roughly $100^{\circ} \mathrm{C}$ increments. The argon composition of each gas increment was measured with an AEI-MS-10S mass spectrometer using computer-controlled peak switching and data acquisition. The total system blank was better than 2 to $3 \cdot 10^{-14}$ moles ${ }^{40} \mathrm{Ar}$ during the course of these experiments.

Argon extractions for the plagioclase and leached groundmass separates were performed with an all-metal Staudacher-type resistance furnace and a MAP-216 mass spectrometer at Stanford University, or with a defocused argon laser beam laser and a MAP-215/50 mass spectrometer at the Free University (Amsterdam). Both systems use two SAES St 172 getters heated to about $250^{\circ} \mathrm{C}$ for gas cleanup; the Amsterdam extraction procedure also used a glass cold finger cooled with a dry ice/alcohol slurry for some samples. The cold system blank for both systems was better than $2 \cdot 10^{-16}$ moles ${ }^{40} \mathrm{Ar}$ during these experiments.

Argon extractions for the plagioclase and groundmass separates were performed with an all-metal Staudacher-type resistance furnace and MAP-216 mass spectrometer at Stanford University, an all-metal Staudacher-type resistance furnace and a MAP-215/50 mass spectrometer at Oregon State University, or with a defocused argon laser beam laser and a MAP-215/50 mass spectrometer at the Free University (Amsterdam). The Amsterdam and Stanford systems use two $\mathrm{Zr}-\mathrm{Zr} / \mathrm{Fe} / \mathrm{V}$ getters heated to about $250^{\circ} \mathrm{C}$ for gas cleanup; the Amsterdam extraction procedure also uses a glass cold finger cooled with a dry ice/alcohol slurry for some samples. The cold system blank for both systems was better than $2 \cdot 10^{-16} 40 \mathrm{Ar}$ moles during the course of this study. The Oregon State extraction system is similar but also has a $\mathrm{Zr} / \mathrm{Al}$ appendage pump heated to about $400^{\circ} \mathrm{C}$ and subsequently cooled during the extraction; the system blank for this system was about $2 \cdot 10^{-15} 40 \mathrm{Ar}$ moles during the course of this study.

Incremental heating experiments were reduced as both age spectra and argon-isotope isochron regressions. Errors have been reported as the standard deviation of analytical precision. Plateau ages were calculated as weighted means, where each step was weighted by the inverse of its variance. Isochron ages were calculated for both the ${ }^{40} \mathrm{Ar} /{ }^{36} \mathrm{Ar}$ vs. ${ }^{39} \mathrm{Ar} /{ }^{36} \mathrm{Ar}$ and ${ }^{36} \mathrm{Ar} /{ }^{40} \mathrm{Ar}$ vs. ${ }^{39} \mathrm{Ar} /{ }^{40} \mathrm{Ar}$ regressions using the York2 least-squares fit with correlated errors (York, 1969); SUMS/N-2 is the $\mathrm{F}$ ratio statistic for this regression. We have found no significant difference between the two regressions when proper error estimates and error correlation coefficients are used (Dalrymple et al., 1988).

\section{RESULTS}

The ${ }^{40} \mathrm{Ar} /{ }^{39} \mathrm{Ar}$ age determinations for the basaltic rocks from the four guyots studied are summarized in Table 1; the complete list of incremental heating data is available from the ODP Data Base Group. Age spectrum diagrams with plateau ages are shown in Figures 4 through 8 . We prefer to use the isochron age rather than the plateau age as the best estimate of the crystallization age of each sample because it (1) combines an estimate of the degree of the internal discordance (the scatter about the isochron line) and an estimate of the analytical error in the final error estimate, and (2) makes no assumption about the composition of the initial nonradiogenic, or trapped, component. The weighted mean ages of distinguishable phases of volcanism at each site, as discussed below, are shown in boldface type in Table 1.

\section{Loen Guyot, Site 872}

Both of the incremental heating experiments (Fig. 4) on the two differentiated alkalic basalt whole-rock samples from Loen Guyot were concordant; the weighted isochron age is $112.8 \pm 1.2 \mathrm{Ma}$. This is significantly older than the Coniacian to early Santonian of the oldest limestones recovered at Site 872 , but agrees well with the early to middle Albian shallow-water debris found in the dredge material from the southern slopes of Loen Guyot by Lincoln et al. (1993).

\section{Wodejebato Guyot Summit Sites 873 through 877}

Four out of the five whole-rock samples (from Sites 873, 874, and 876) dated from the summit lavas recovered at Wodejebato Guyot yielded concordant incremental heating data (Fig. 5). The weighted 
Table 1. Radiometric ages of Leg 144 basalts.

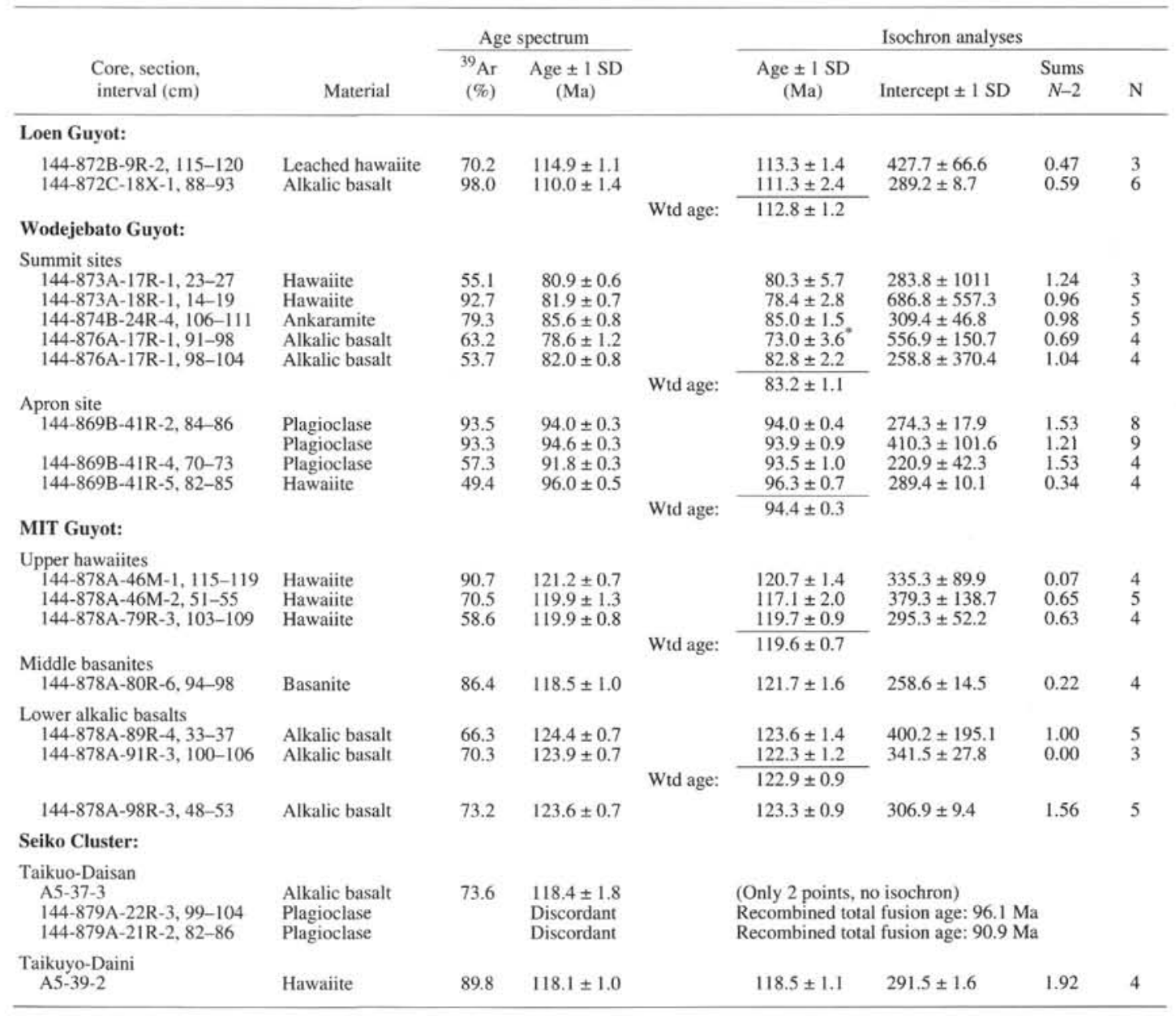

Notes: All ages reported relative to 85 G003 TCR sanidine at 27.92 Ma except for the A5-37-3 and A5-39-2 dredge samples, which are relative to FCT-3 biotite at 27.7 Ma. SD = standard deviation, and Wtd. $=$ weighted. Single asterisk $(*)=$ discordant, not used in weighted age calculation.

mean age of the concordant isochron analyses is $83.2 \pm 1.1 \mathrm{Ma}$. The $95 \%$ confidence interval of both the individual and mean isochron ages confirms that the reversed magnetic polarity of all of the drilled basement sections indicates that all of the basement lavas at Wodejebato Guyot formed during Chron 33R, ca. 79-83 Ma (Fig. 2). The fifth experiment (Sample 144-876A-17R-1, 91-98 cm) is discordant, with a stepwise decreasing age spectrum usually attributed to ${ }^{39} \mathrm{Ar}$ recoil in fine-grained samples (Fig. 5); the lowest and highest temperature steps of the age plateau are significantly different at the $95 \%$ confidence level. The apparent age of that fifth sample (73.0 \pm $3.6 \mathrm{Ma}$ ) is similar to, but significantly younger than, the $83.2-\mathrm{Ma}$ weighted age of the other samples.

\section{Wodejebato/Pikini Apron Site 869, Leg 143}

All of the incremental heating experiments of the samples from the volcaniclastic breccia sampled at Hole 869B were concordant (Table 1 and Fig. 6). The weighted age of the four experiments is 94.4 $\pm 0.3 \mathrm{Ma}$. Strictly speaking, one of the plagioclase experiments and the whole-rock experiment are significantly different at the $95 \%$ confidence level. Thus, it is most correct to consider the ages as two distinct volcanic events: the plagioclase-phyric clasts, with a weighted age of $93.9 \pm 0.3 \mathrm{Ma}$, and the hawaiite, at $96.3 \pm 0.7 \mathrm{Ma}$.

\section{MIT Guyot, Site 878}

All of the incremental heating experiments on the seven wholerock samples from Site 878 on MIT Guyot were concordant (Table 1 and Fig. 7). The three hawaiites, one from the basement upper lava sequence and two from clasts found near the top of the polymict breccia, formed a younger, analytically distinct group. The weighted mean isochron age for these upper hawaiites is $119.6 \pm 0.7 \mathrm{Ma}$ (Table 1). The lone basanite, $121.7 \pm 0.7 \mathrm{Ma}$, is intermediate in age between, although not statistically distinct from, the upper hawaiites and lower basalts. The three lower basalts average $123.1 \pm 0.6 \mathrm{Ma}$. The best age for the top of the reversed polarity Chron seen in the lower basalts is the $122.9 \pm 0.9 \mathrm{Ma}$ weighted mean of the two flows closest to the transition (Core 144-878A-89R-4 from within the zone of transitional polarity, and Core 144-878A-91R-3, with reversed polarity, from just below the transition).

\section{Takuyo-Daisan Guyot Site 879 and Dredge Samples}

The incremental heating experiments on the two plagioclase separates from the peperite at the base of Hole $879 \mathrm{~A}$ were surprisingly discordant, yielding no plateau in the age spectrum diagram (Fig. 8) and a complicated $\mathrm{K} / \mathrm{Ca}$ release pattern (not shown). We interpret the 

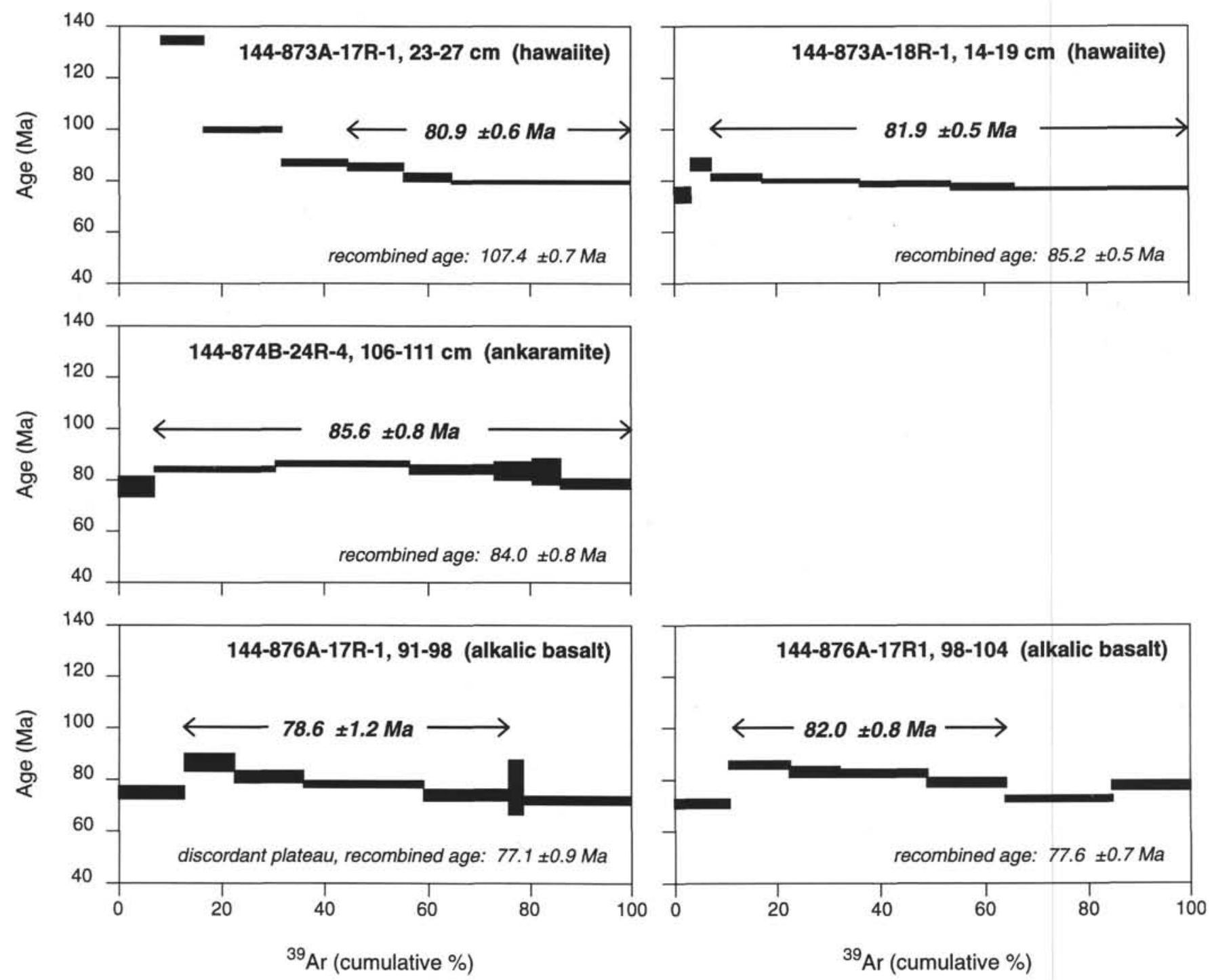

Figure 5. Age spectra of incremental heating experiments on whole-rock samples from the summit of Wodejebato Guyot, Sites 873 through 876 . Individual step ages are drawn \pm 1 standard deviation of the apparent age.

best age estimates from these experiments $(90.9$ and 96.1 Ma recombined total fusion ages) as minimum age estimates only. We plan further work examining why these apparently clean plagioclase separates did not yield concordant crystallization ages, and we suspect that the red and green discoloration of the basalts may hint at some alteration that we do not yet recognize. However, the two dredge samples did reveal incremental heating experiments concordant with the age of the oldest platform carbonate recovered at Site 879 (Fig. 3). The best result is on the sample from nearby Takuyo-Daini Seamount (A5-37-3); the isochron age of $118.5 \pm 1.1 \mathrm{Ma}$ is the best estimate of the age of basaltic volcanism in the Seiko seamount cluster. The twostep, low-temperature plateau age of $118.4 \pm 1.8 \mathrm{Ma}$ for Sample A5-39-2 (Fig. 8), containing $73.6 \%$ of the ${ }^{39}$ Ar released, suggests a similar age of volcanism for Takuyo-Daisan.

\section{DISCUSSION AND CONCLUSIONS Origin in the SOPITA}

${ }^{40} \mathrm{Ar} /{ }^{39} \mathrm{Ar}$ incremental heating experiments have yielded reliable estimates of the crystallization age of the volcanic rocks sampled from at least four Cretaceous edifices in the northwest Pacific Ocean.
Using these ages and stage rotation poles describing Pacific/hotspot motion (such as those of Duncan and Clague, 1985), we can backtrack the current location of these sites to the positions where they formed (Fig. 1). All of these sites had sources in the central and western regions of Staudigel et al.'s (1991) modern South Pacific Isotopic and Thermal Anomaly (SOPITA), a region of extreme isotopic diversity and thermal anomalies in the mantle source of recent South Pacific seamount and ocean island basalts, extending from Easter Island, through French Polynesia, to the Samoan Islands. Volcanism in the Seiko Cluster of the Japanese Seamounts, including Site 879, had an origin near Tahiti in the Society Islands. MIT Guyot, Site 878, had a source in the northwestern SOPITA between the Marquesas and Samoan islands. Volcanism in the Marshall Islands, including Loen and Wodejebato guyots, had an origin near the southern limit of the modern SOPITA, in and south of the Austral-Cook Islands. Possible errors in the original location of these seamounts, principally from errors in the stage poles and an inherent sampling bias because we tend to recover only the uppermost (i.e., youngest) products of volcanism at any given site, prevent a precise comparison between the locations of the Cretaceous and modern hotspots, but the general origin of these Cretaceous seamounts in the SOPITA is clear. 

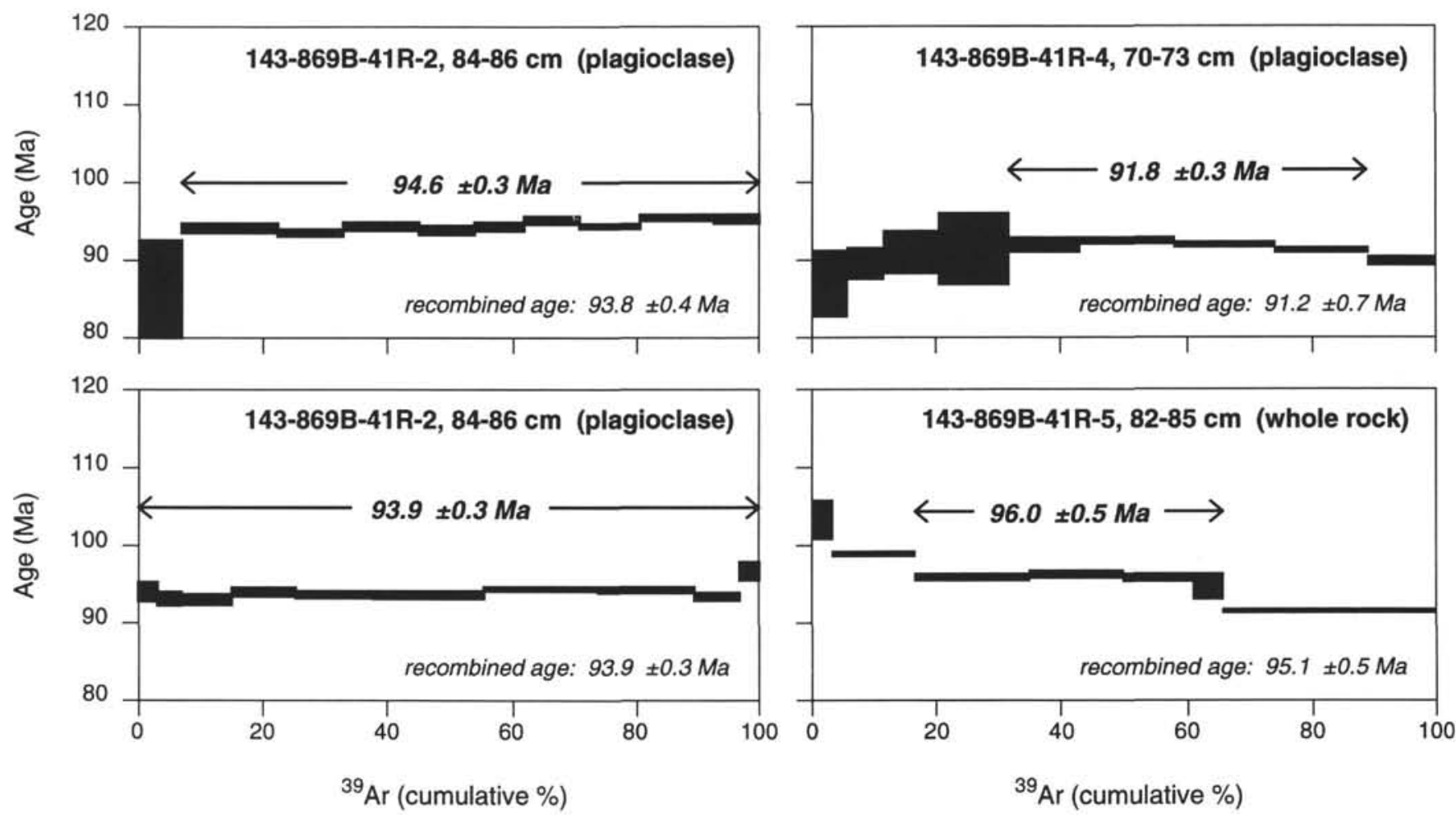

Figure 6. Age spectra of incremental heating experiments on whole-rock samples and plagioclase separates from Hole 869B, drilled on the archipelagic apron southeast of Wodejebato Guyot and Pikini Atoll. Individual step ages are drawn \pm 1 standard deviation of the apparent age.

\section{Implications for Drowned Guyot/Atoll Pairs}

One of the questions to be addressed by the Guyot and Atoll Drilling Program was why some Cretaceous carbonate platforms survive as atolls today, whereas other, "sister" Cretaceous platforms did not. For example, Loen is the "sister" guyot to the living Anewetak Atoll, with whom it shares a common constructional edifice. However, we now know that the age of volcanism at the two volcanoes is significantly different: $113 \mathrm{Ma}$ for Loen Guyot (this study), but $76 \mathrm{Ma}$ for Anewetak (Lincoln et al., 1993). Perhaps at least some guyot/atoll pairs are simply unrelated volcanoes built on the same constructional base. Many of the older of the pairs could have formed in the Early Cretaceous, been affected by the same (as yet unknown) mechanism that seems to have drowned all of the known Cretaceous reefs in the western Pacific by latest Albian/Cenomanian time (e.g., see Winterer et al., 1993), and subsided below the photic zone. A younger, opportunistic volcano could have begun on the existing base of an older edifice, grown to sea level, and established a significantly younger shallow-water carbonate community, but not affected the nearby older edifice enough to bring it back into the photic zone. The Marshall Islands, which seems to have been a literal crossroads of Cretaceous volcanism and hotspot tracks (cf. Lincoln et al., 1993; Bergersen, this volume) would have been an ideal region for such random co-occurrences.

\section{Inherent Bias \\ in Dredged and Drilled Summit Samples}

The volcanic basement at the summit of Wodejebato Guyot, including the basal breccias, is all reversely magnetized (Premoli Silva, Haggerty, Rack, et al., 1993). The ${ }^{40} \mathrm{Ar} /{ }^{39} \mathrm{Ar}$ ages of the lavas reported here, as well as those dredged from the northeast rift zone (M. Pringle and A. Koppers, unpubl. data), are all 85-79 Ma. The only significant reversely magnetized period between 73 and about $120 \mathrm{Ma}$ is Chron 33R. Thus, all of the recovered lavas from near the summit of Wode- jebato Guyot must have erupted during magnetic Chron 33R, from 83 to $79 \mathrm{Ma}$ (Fig. 2). This Campanian volcanism most likely provided the source for the thick volcanogenic sands seen in the Campanian section of Site 869 . However, these ages are significantly younger than the reworked Cenomanian nannofossils found at Site 877, the Cenomanian to Albian (?) rudists dredged from the southwestern flanks of Wodejebato (Lincoln et al., 1993), and the 96-94 Ma ${ }^{40} \mathrm{Ar}{ }^{39} \mathrm{Ar}$ ages of basaltic clasts recovered in the even thicker Cenomanian turbidites at the Site 869 apron hole. Thus, there must have been a Cenomanian or older volcanic edifice at Wodejebato Guyot, even though it was not sampled by the five summit sites drilled during Leg 144.

It is important to note that the only actual samples of this Cenomanian or older volcanism are from the volcaniclastic deposits drilled in the archipelago apron site, $45 \mathrm{nmi}$ away. This suggests that we must be cautious when deciphering the volcanic history of large submarine edifices from limited sample sets, and that drilling through volcaniclastic apron sites may be the best (only?) way to sample the complete volcanic history of large seamounts, guyots, and oceanic plateaus.

\section{Age of the Top of Chron M1R}

The $122.9 \pm 0.9 \mathrm{Ma}$ age of the top of the reversed-polarity chron seen in the basement lavas of MIT Guyot provides an important calibration point for the mid-Cretaceous Geologic Reversal Time Scale (GRTS), especially if we can unambiguously identify which reversal we are dating. As discussed above, the oldest dated sediments, platform carbonates located approximately $25 \mathrm{~m}$ above volcanic basement, are attributable to the lower part of the $C$. litterarius nannofossil Zone (Fig. 3, above the first occurrence of $R$. irregularis, below the nannoconid crisis). The reversed-polarity Chron M0 occurs entirely within this lower part of the $C$. litterarius Zone, but 300-350 $\mathrm{ka}$ is represented by the normal polarity interval time between the top of Chron M0 and the nannoconid crisis (Herbert, 1992; Erba, 1994). Thus, the reversal seen in the basement basalts could be the top of 

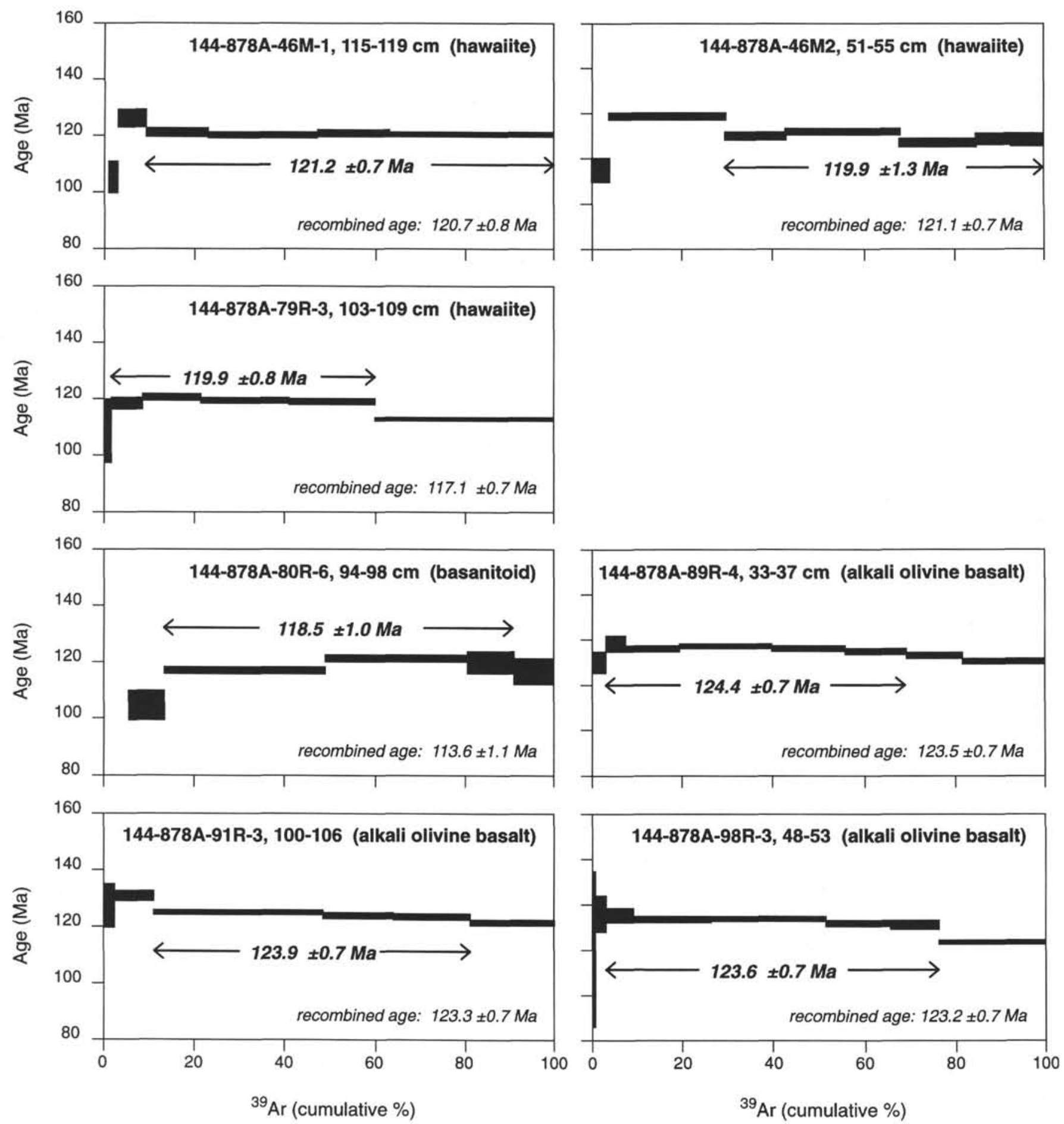

Figure 7. Age spectra of incremental heating experiments on whole-rock samples from Hole 878A, drilled on the summit of MIT Guyot. Individual step ages are drawn \pm 1 standard deviation of the apparent age.

magnetic polarity Chron M0 if the entire normally magnetized sequence below Core 144-878 A-75R was formed in this $300-350 \mathrm{Ka}$ normal polarity interval, that is, (1) if the shallow-water carbonates were deposited significantly faster than about $75 \mathrm{~m} / \mathrm{m}$.y., (2) if there was no significant hiatus between the eruption of the top of the reversed basalts and the deposition of the first carbonates, and (3) if the time represented by the weathering horizons and basalt to basanitoid to hawaiite volcanic evolution in the basement sequence is also not significant.
However, given the much more likely occurrence of at least one of (1) slower sedimentation rates, (2) a missed reversal could in the lower sedimentary sequences, (3) a significant hiatus between the youngest lavas and the development of the initial carbonate reef, (4) significant time represented by the two weathering profiles seen in the basalt sequence above the reversal, and (5) significant time represented by the volcanic evolution seen in the basement sequence, the magnetic reversal seen in the basalts must be older than the top of Chron M0, that is, the top of magnetic polarity Chron M1R. From 

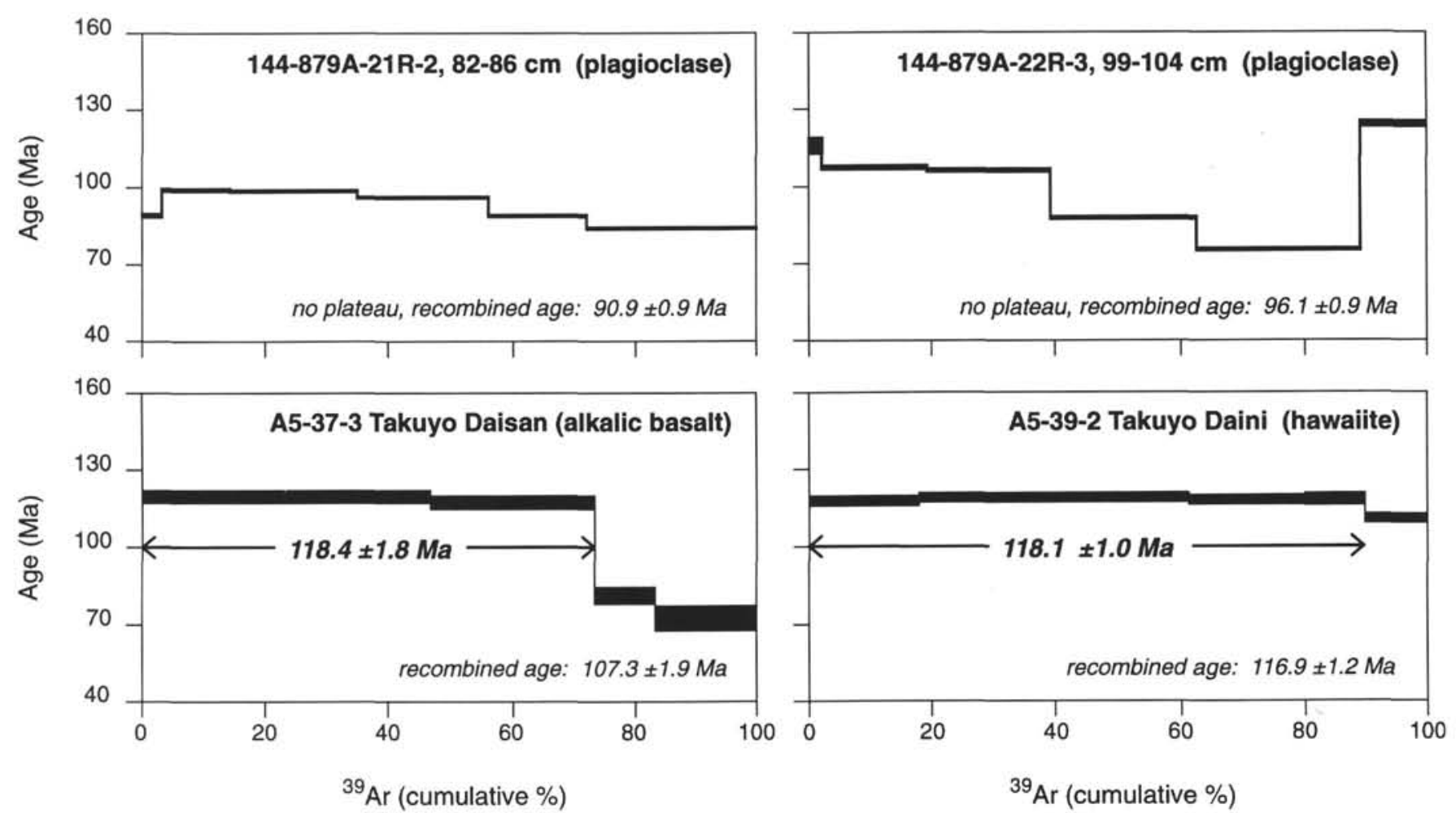

Figure 8. Age spectra of incremental heating experiments on whole-rock samples and plagioclase separates from Hole 879, drilled on the summit of Takuyo-Daisan Guyot. Individual step ages are drawn \pm 1 standard deviation of the apparent age.

the 122.9-Ma age of the transition basalts and the 2.5-m.y. duration of Chron MIN (Herbert, 1992; Channel et al., in press), we can calculate an age of $120.4 \mathrm{Ma}$ for the base of Chron M0, very near the Barremian/Aptian boundary (Fig. 3), confirming the revised 121-Ma estimate for the age of this stage boundary (Channel et al., in press; Gradstein et al., in press) compared to the older 124.5-Ma estimate of Harland et al. (1990).

Note (added in proof): To confirm the identification of the magnetic polarity transition drilled at Site 878 on MIT Guyot, four incremental heating experiments on plagioclase separates from the same samples from Sections 144-878A-89R-4 and -91R-3 studied above were performed after the initial submission of this manuscript. The weighted mean age obtained from these experiments (122.8 $\pm 0.2 \mathrm{Ma})$ is consistent with, but considerably more precise than, the $122.9 \pm 0.9$ Ma whole-rock ages of the transition reported above. In particular, the new age allows us to state, at the $95 \%$ confidence level, that the upper hawaiites at Hole $878 \mathrm{~A}$ are at least 1.4 Ma younger than the lower basalts marking the polarity transition. Thus, the entire normally magnetized sequence below Core 144-878A-75R cannot possibly have been deposited in the 300- to 350-ka interval above Chron M0 still below the nannoconid crisis, confirming our identification of the reversal as the top of Chron M1R, as shown in Figure 3.

\section{ACKNOWLEDGMENTS}

We thank Dave Christie, Phil Janey, Pat Castillo, and Jim Natland for assistance with initial sample selection of the Leg 144, Site 869, and Aries V samples. The reactor staff of the Oregon State University TRIGA facility provided all of the required fast neutrons. Lew Hogan of the College of Oceanic and Atmospheric Sciences keeps the argon geochronology laboratory at OSU going and helped run some of the analyses reported here. Accommodations in Corvallis for M. Pringle were provided courtesy of the Christie Hilton, Ltd. This research was partially supported by JOI/USSAC post-cruise science grants 14420743 and 143-20706 to R. Duncan at Oregon State University, JOI/USSAC post-cruise science grant 143-20759B to M. Pringle and M. McWilliams at Stanford University, and a NSF International Postdoctoral Fellowship to M. Pringle at the Free University (Amsterdam). J. O'Connor, Marcia McNutt, and an anonymous reviewer provided useful reviews of the manuscript.

\section{REFERENCES}

Channel, J.E.T., Erba, E., Nakanishi, M., and Tamaki, K., in press. Late Jurassic-Early Cretaceous time scales and oceanic magnetic anomaly block models. AAPG Spec. Vol.

Dalrymple, G.B., Alexander, E.C., Lanphere, M.A., and Kraker, G.P., 1981. Irradiation of Samples for ${ }^{40} \mathrm{Ar}{ }^{39} \mathrm{Ar}$ Dating Using the Geological Survey TRIGA Reactor: Geol. Surv. Prof. Pap. U.S., 1176.

Dalrymple, G.B., Lanphere, M.A., and Clague, D.A., 1980. Conventional and ${ }^{40} \mathrm{Ar} /{ }^{39} \mathrm{Ar} \mathrm{K}$-Ar ages of volcanic rocks from Ojin (Site 430), Nintoku (Site 432 ) and Suiko (Site 433) seamounts and the chronology of volcanic propagation along the Hawaiian-Emperor Chain. In Jackson, E.D., Koizumi, I., et al., Init. Repts. DSDP, 55: Washington (U.S. Govt. Printing Office), 659-676.

Dalrymple, G.B., Lanphere, M.A., and Pringle, M.S., 1988. Correlation diagrams in ${ }^{40} \mathrm{Ar} /{ }^{39} \mathrm{Ar}$ dating: is there a correct choice? Geophys. Res. Lett., 15:589-591.

Duncan, R.A., and Clague, D.A., 1985. Pacific plate motion recorded by linear volcanic chains. In Nairn, A.E.M., Stehli, F.G., and Uyeda, S. (Eds.), The Ocean Basins and Margins (Vol. 7A): The Pacific Ocean: New York (Plenum), 89-121.

Erba, E., 1994. Nannofossil and superplumes: the early Aptian "nannoconnid crisis." Paleoceanography, 9:483-501.

\footnotetext{
-Abbreviations for names of organizations and publications in ODP reference lists follow the style given in Chemical Abstracts Service Source Index (published by American
} Chemical Society). 
Gradstein, F.M., Agterberg, F.P., Ogg, J.G., Hardenbol, J., and Huang, Z., in press. A Mesozoic time scale. J. Geophys. Res.

Harland, W.B., Armstrong, R.L., Cox, A.V., Craig, L.E., Smith, A.G., and Smith, D.G., 1990. A Geologic Time Scale 1989: Cambridge (Cambridge Univ. Press).

Hart, S.R., 1984. A large-scale isotope anomaly in the Southern Hemisphere mantle. Nature, 309:753-757.

Heezen, B.C., Matthews, J.L., Catalano, R., Natland, J., Coogan, A., Tharp, M., and Rawson, M., 1973. Western Pacific guyots. In Heezen, B.C. MacGregor, I.D., et al., Init. Repts. DSDP, 20: Washington (U.S. Govt. Printing Office), 653-723.

Herbert, T.D., 1992. Paleomagnetic calibration of Milankovitch cyclicity in Lower Cretaceous sediments. Earth Planet. Sci. Lett., 112:15-28.

Lanphere, M.A., and Dalrymple, G.B., 1978. The use of ${ }^{40} \mathrm{Ar} /{ }^{39} \mathrm{Ar}$ data in evaluation of disturbed K-Ar systems. In Zartman, R.E. (Ed.), Short Papers of the Fourth International Conference, Geochronology, Isotope Geology. Open-File Rep.-U.S. Geol. Surv., 78-701:241-243.

Lincoln, J.M., Pringle, M.S., and Premoli-Silva, I., 1993. Early and Late Cretaceous volcanism and reef-building in the Marshall Islands. In Pringle, M.S., Sager, W.W., Sliter, W.V., and Stein, S. (Eds.), The Mesozoic Pacific: Geology, Tectonics, and Volcanism. Geophys. Monogr., Am. Geophys. Union, 77:279-305.

Mutterlose, J., 1991. Das Verteilungs- und Migrationsmuster des kalkigen Nannoplanktons in der borealen Unterkreide (Valangin.-Apt.) NWDeutschlands. Palaeontographica B, 221:27-152.

Premoli Silva, I., Haggerty, J., Rack, F., et al., 1993. Proc. ODP, Init. Repts., 144: College Station, TX (Ocean Drilling Program).
Pringle, M.S., 1993. Age progressive volcanism in the Musicians Seamounts: a test of the hot-spot hypothesis for the Late Cretaceous Pacific. In Pringle, M.S., Sager, W.W., Sliter, W.V., and Stein, S. (Eds.), The Mesozoic Pacific: Geology, Tectonics, and Volcanism. Geophys. Monogr., Am. Geophys. Union, 77:187-215.

Pringle, M.S., and Duncan, R.A., 1995. Radiometric ages of basaltic lavas recovered at Sites 865,866 , and 869 . In Winterer, E.L., Sager, W.W., Firth, J.V., and Sinton, J.M. (Eds.), Proc. ODP, Sci. Results, 143: College Station, TX (Ocean Drilling Program), 277-283.

Sager, W.W., Winterer, E.L., Firth, J.V., et al., 1993. Proc. ODP, Init. Repts., 143: College Station, TX (Ocean Drilling Program).

Staudigel, H., Park, K.-H., Pringle, M., Rubenstone, J.L., Smith, W.H.F., and Zindler, A., 1991. The longevity of the south Pacific isotopic and thermal anomaly. Earth Planet. Sci. Lett., 102:24-44.

Winterer, E.L., Natland, J.H., van Waasbergen, R.J., Duncan, R.A., McNutt, M.K., Wolfe, C.J., Premoli Silva, I., Sager, W.W., and Sliter, W.V., 1993. Cretaceous guyots in the Northwest Pacific: an overview of their geology and geophysics. In Pringle, M.S., Sager, W.W., Sliter, W.V., and Stein, S. (Eds.), The Mesozoic Pacific: Geology, Tectonics, and Volcanism. Geophys. Monogr., Am. Geophys. Union, 77:307-334.

York, D., 1969. Least-squares fitting of a straight line with correlated errors. Earth Planet. Sci. Lett., 5:320-324.

Date of initial receipt: 1 February 1994

Date of acceptance: 15 July 1994

Ms 144SR-033 